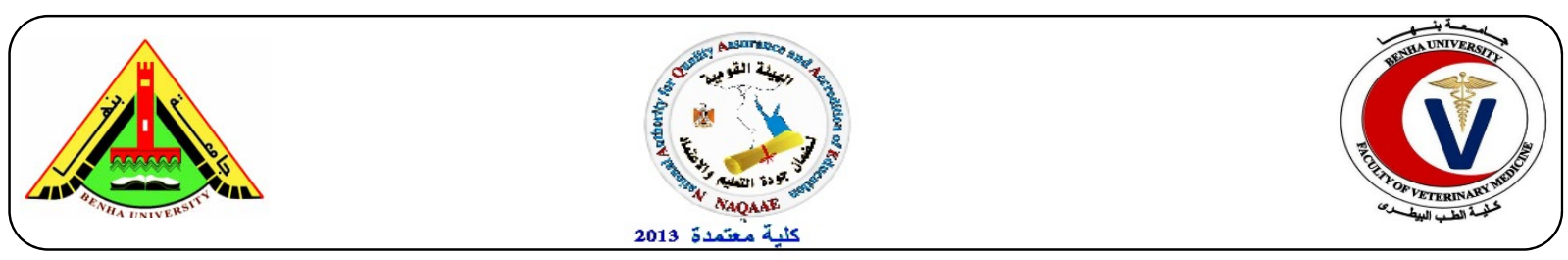

\title{
Studies on bacteriological Profile of some meat products
}

\author{
Fahim A. Shaltout ${ }^{\mathrm{a}}$, Amani. M. Salem ${ }^{\mathrm{a}}$, Dalia F. Khater ${ }^{\mathrm{b}}$ and Radwa. A Lela ${ }^{\mathrm{b}}$ \\ ${ }^{a}$ Department of Food Control, Faculty of Veterinary Medicine, Benha University, Egypt. ${ }^{b}$ Department of Food \\ Hygiene., Animal Health Research Institute., Tanta branch.
}

\begin{abstract}
A B S T R A C T
A total of 100 random samples of meat products represented by luncheon, frozen minced meat, kofta, and sausage ( 25 of each) were collected from different supermarket's shops in Tanta city These products subjected to bacteriological examination as Aerobic Plate Count (APC), Coliform Count, Staph. aureus count and isolation and identification of Salmonellae and E-Coli. The result revealed that minced meat showed relatively higher mean values of Aerobic Plate

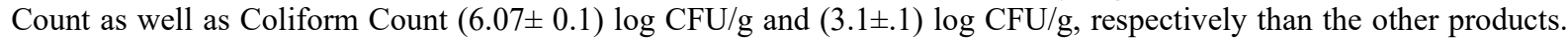
While, it was the lowest one in Staph aureus count (2.2 .07) $\log$ CFU/g. Regarding to Salmonellae and E-Coli could be detected in $40 \% \& 32 \% \& 12 \% \& 28 \% \& 16 \% \& 24 \%$ of minced meat, kofta and sausage, respectively On the other hand, luncheon samples were free from Salmonella and E-coli.
\end{abstract}

KEYWORDS: Minced meat, luncheon, kofta, E-coli, Staphylococcus aureus, Aerobic plate count

(http://www.bvmj.bu.edu.eg)

(BVMJ-31(1): 43-49, 2016)

\section{INTRODUCTION}

In recent years, there has been a steady increase in the production and consumption of processed meat products worldwide because of their high nutritive value and convenience. (Rajic'et al., 2007). Meat products are subjected to contamination with several types of microorganisms from different sources during preparation, processing and serving to consumers. These microorganisms varied according to the method of manufacture, quality of used non- meat ingredient, and contamination level during the processing chain, packaging and storage (Borch and Arinda, 2002). Raw meat may harbor many important pathogenic microbes i.e. E. coli, Salmonellae spp. and Staph. aureus making the meat a risk for human health, as without the proper handling and control of these pathogens, food borne ill-nesses may occur (Nørrung et al., 2009). Accurately, up to 4000 deaths and 5 million illnesses each year is caused by contaminated meat and meat products with food poisoning bacteria particularly, E. coli, Salmonella, S. aureus (APHA,1984). Staphylococcus aureus is an important cause of food intoxication throughout the world. This bacterium can contaminate several foods, including minimally processed meat products and produce several types of enterotoxins (Naomi and Avraham, 2000). Moreover, detection of Coliforms is used as a general indicator of sanitary condition in the food-processing environment (Feng et al., 2002).

Also, contamination of minced meat with Salmonella is still considered a major problem in food hygiene (Vipham et al., 2012). Humans become infected with Salmonella primarily through faecal contamination of food products or water. Another source of human infection, primarily affecting farm families, employees, and visitors is contact with ill animals (Wells et al., 2001). Salmonellosis is still one of the major global causes of gastroenteritis in humans and animals (Grimont and Weil, 2007). Insufficient cooking may result in survival of E-coli and subsequently causes food poisoning to consumers (Cruz et al., 2005). E -coli is commonly non virulent but some strains have adopted pathogenic or toxigenic virulence factors that make them serious for man and animals (Donald et al., 2001).

Therefore, the present study is planned out to detect bacteriological profile of some meat products to ensure consumer safety.

\section{MATERIAL AND METHODS}

\subsection{Samples:}

A total of 100 samples of various types of packed meat products as luncheon and frozen minced meat, kofta, and sausage (25 of each) were 
randomly collected from different supermarkets at different production dates in Tanta city, El-Gharbia governorate, Egypt. The samples were taken and transferred directly to the laboratory under complete aseptic conditions without undue delay and subjected to Bacteriological examinations.

\subsection{Preparation of Samples:}

according to ICMSF, (1978). A $10 \mathrm{~g}$ portion of each sample was aseptically weighted into $90 \mathrm{ml}$ of $0.1 \%$ peptone water in a sterile plastic bag, and then blended in a Stomacher 400 Lab Blender (Seward Medical, London, UK) for 30 seconds. Ten-fold serial dilutions were used for bacteriological examination.

\subsection{Bacteriological examination:}

Aerobic Plate Count and Coliform Count were carried out according to APHA, (1992) Staph. aureus Counting, Isolation and identification of $E$. coli were carried out according to ICMSF, (1996). Isolation and identification of Salmonellae was carried out according to ISO, (2002). Serological identification of Salmonellae according to Kauffman, (1974) and E-Coli according to Varnam and Evans (1991)

\section{RESULTS}

The mean values $(\log \mathrm{CFU} / \mathrm{g})$ of aerobic plate,

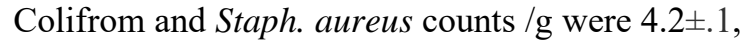

$2.6 \pm .1$ and $2.5 \pm .1$ in luncheon, $6.1 \pm 0.1,3.1 \pm .1$ and $2.2 \pm .1$ in minced meat, $5.8 \pm 0.1,2.6 \pm .1$ and $2.5 \pm .2$ in kofta and $4.8 \pm 0.1,2.9 \pm .01$ and $2.6 \pm .1$ in sausage, respectively. There was a significant difference at level $(P<0.05)$ between the examined samples. (table 1). Moreover, as shown in Table (2) $60 \%, 28 \%$ and $16 \% \& 52 \%$, - and $20 \% \& 16 \%$,- and $8 \%$ and,$- 20 \%$ and $24 \%$ of examined samples of luncheon, frozen minced meat, kofta and sausage were unacceptable for APC, Coliform and $S$. aureus Counts according to permissible limit recommended by E.O.S. (2005a-b-c-d). Furthermore, the results in table (3) revealed that Salmonella spp was detected in minced meat $(40 \%)$, kofta $(12 \%)$ and sausages $(16 \%)$, while it failed to be detected in luncheon samples. Consequently, they serologically identified as Salmonella. Enteritidis, S. Typhimurium, S. Newport, S. Antum and S. Typhi. Also, the results recorded in tables (4) revealed that the highest rate of contamination with $E$. coli was recorded in minced meat (32\%) followed by kofta $(28 \%)$ but lowest one found in sausage (24\%). While, E-coli was failed to be detected in luncheon samples. Moreover, E. coli serotypes were serologically identified as O55: K59, O125:K70, O124:K72 and O119:K69, O111: K58, O128:K67and O119:K69 Finally, O124:K72, O111:K58 and O126:K71 in minced meat, kofta and sausage samples, respectively.

Table (1) Mean values of (APC-Coliform-Staph. aureus) of examined meat product samples

\begin{tabular}{lcccccc}
\hline Meat products & Microorganisms & \multicolumn{2}{c}{ Positive samples } & Min & Max & Mean \pm SE* \\
& & No & $\%$ & & & \\
\hline Luncheon & APC & 25 & 100 & 3.00 & 4.95 & $4.2 \pm .1$ \\
& Coliform & 7 & 28 & 2.30 & 2.90 & $2.6 \pm .1$ \\
& Staph. aureus & 4 & 16 & 2.30 & 2.78 & $2.5 \pm .1$ \\
Minced meat & APC & 25 & 100 & 5.08 & 6.98 & $6.1 \pm .1$ \\
& Coliform & 9 & 36 & 2.60 & 3.78 & $3.1 \pm .1$ \\
& Staph. aureus & 5 & 20 & 2.00 & 2.30 & $2.2 \pm .1$ \\
Kofta & APC & 25 & 100 & 5.00 & 6.94 & $5.8 \pm .1$ \\
& Coliform & 8 & 32 & 2.30 & 2.90 & $2.6 \pm .1$ \\
\multirow{5}{*}{ Sausage } & Staph. aureus & 2 & 8 & 2.30 & 2.60 & $2.5 \pm .15$ \\
& APC & 25 & 100 & 4.08 & 5.9 & $4.8 \pm .10$ \\
& Coliform & 5 & 20 & 2.48 & 3.30 & $2.9 \pm .01$ \\
& Staph. aureus & 6 & 24 & 2.30 & 2.90 & $2.6 \pm .10$ \\
\hline
\end{tabular}

*significant differences $(P<0.05)$ 
Table (2) Acceptability of the examined meat products in comparison to E.O.S. (2005)

\begin{tabular}{lcccccccc}
\hline Meat products & Microorganisms & \multicolumn{2}{c}{ Positive samples } & \multicolumn{2}{c}{ Accepted } & \multicolumn{2}{c}{ Unaccepted } & $\begin{array}{c}\text { E.O.S.Q.C, } \\
(2005)\end{array}$ \\
& & No & $\%$ & No & $\%$ & No & $\%$ & \\
\hline Luncheon & APC & 25 & 100 & 10 & 40 & 15 & 60 & $10^{4}$ \\
& Coliform & 7 & 28 & - & - & 7 & 28 & $10^{2}$ \\
Minced meat & Staph. aureus & 4 & 16 & - & - & 4 & 16 & 0 \\
& APC & 25 & 100 & 12 & 48 & 13 & 52 & $10^{6}$ \\
& Coliform & 9 & 36 & - & - & - & - & - \\
Kofta & Staph. aureus & 5 & 20 & - & - & 5 & 20 & $10^{2}$ \\
& APC & 25 & 100 & 21 & 84 & 4 & 16 & $10^{6}$ \\
Sausage & Coliform & 8 & 32 & - & - & - & - & - \\
& Staph. aureus & 2 & 8 & - & - & 2 & 8 & $10^{2}$ \\
& APC & 25 & 100 & 25 & 100 & - & - & $10^{6}$ \\
& Coliform & 5 & 20 & - & - & 5 & 20 & $10^{2}$ \\
& Staph. aureus & 6 & 24 & - & - & 6 & 24 & $10^{2}$ \\
\hline
\end{tabular}

Table (3) Incidence and serotyping of salmonella species isolated from examined samples of meat products

\begin{tabular}{|c|c|c|c|c|c|c|c|c|}
\hline \multirow[t]{3}{*}{ Strains } & \multicolumn{2}{|c|}{ Luncheon } & \multicolumn{2}{|c|}{ Minced meat } & \multicolumn{2}{|c|}{ Kofta } & \multicolumn{2}{|c|}{ Sausage } \\
\hline & & & No & $\%$ & & & & \\
\hline & No & $\%$ & & & No & $\%$ & No & $\%$ \\
\hline S. Enteritidis & - & - & 5 & 20 & 1 & 4 & 1 & 4 \\
\hline S. Typhi & - & - & 1 & 4 & 0 & 0 & - & - \\
\hline S. Typhimurium & - & - & 2 & 8 & 2 & 8 & 1 & 4 \\
\hline S. Anatum & - & - & 1 & 4 & - & - & 1 & 4 \\
\hline S. Newport & - & - & 1 & 4 & - & - & 1 & 4 \\
\hline Total & - & - & 10 & $40^{*}$ & 3 & $12 *$ & 4 & $16^{*}$ \\
\hline
\end{tabular}

Table (4) Incidence and serotyping of E-Coli species isolated from examined samples of meat products.

\begin{tabular}{|c|c|c|c|c|c|c|c|c|}
\hline \multirow{2}{*}{$\begin{array}{l}\text { Identified } \\
\text { strains }\end{array}$} & \multicolumn{2}{|c|}{ Luncheon } & \multicolumn{2}{|c|}{ Minced meat } & \multicolumn{2}{|c|}{ Kofta } & \multicolumn{2}{|c|}{ sausage } \\
\hline & no & $\%$ & no & $\%$ & no & $\%$ & no & $\%$ \\
\hline O55:K59 & - & - & 2 & 8 & - & - & - & - \\
\hline O111: K58 & - & - & - & - & 3 & 12 & 2 & 8 \\
\hline O124: K72 & - & - & 2 & 8 & - & - & 2 & 8 \\
\hline O125: K70 & - & - & 1 & 4 & - & -- & - & - \\
\hline O126: K71 & - & - & 2 & 8 & - & - & 2 & 8 \\
\hline O128:K67 & - & - & - & - & 2 & 8 & - & - \\
\hline O119: K69 & - & - & 1 & 4 & 2 & 8 & - & - \\
\hline total & - & - & 8 & $32 *$ & 7 & $28 *$ & 6 & $24 *$ \\
\hline
\end{tabular}

*Samples exceeded permissible limit according to E.O.S.Q.C (2005a-b-d).

\section{DISCUSSION}

Aerobic Plate Count of any food article is not a sure indicative for its safety for consumption, yet it is of supreme importance in judging the hygienic conditions under which it has been produced, handled and stored (Jay, 1997). The results illustrated in table (1) revealed that Aerobic Plate Count was in agree with Erdem-Ayten et al. (2014) (9x $10^{6} \mathrm{CFU} / \mathrm{g}$ in minced meat). But lower ones were reported by Salem-Amany et al., (2010) (5.61 $\mathrm{x} 10^{5} \mathrm{CFU} / \mathrm{g}$ in minced meat) and El-Dosoky et al.
(2013) (3.6 log CFU/g in luncheon) and (3.6 log $\mathrm{CFU} /$ gin sausage). Higher result was reported by Gönülalan and Köse (2003) that was $\left(5.3 \times 10^{9}\right.$ in minced meat). High Aerobic Plate Count may be attributed to the contamination of the product from different sources or unsatisfactory processing as well as unsuitable condition during storage (Zaharan-Dalia, 2008).

Regarding to Coliform Count results were nearly similar to those obtained by Salem-Amany et al. (2010) $\left(5.12 \times 10^{3} \mathrm{CFU} / \mathrm{g}\right.$ in minced meat). Meanwhile, higher result was obtained by El- 
Dosoky et al. (2013) were (3.1 and $3 \log$ CFU/g in luncheon and sausage, respectively). and, ErdemAyten et al. (2014) $\left(4.5 \times 10^{7} \mathrm{cfu} / \mathrm{g}\right.$ in minced meat). Consequently, high Coliforms count indicates poor hygienic quality of meat and may be responsible for economic losses and presence of enteric pathogens which constitute public health hazards (Yadav et al.,2006). Also, results of S. aureus were similar to those obtained by Morshdy et al. (2013) $\left(4.3 \times 10^{2} / \mathrm{g}\right.$ in minced meat), Hassanien-Fatin, (2004) $\left(7.01 \times 10^{2} / \mathrm{g}\right.$ in luncheon). Higher result obtained by Al- kour (2001) $\left(4.13 \times 10^{3} / \mathrm{g}\right.$ in minced

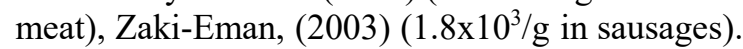
and Hassanien-Fatin, (2004) $\left(1.12 \times 10^{4} / \mathrm{g}\right.$ in sausages and $2.51 \times 10^{3} / \mathrm{g}$ in kofta). Presence of $S$. aureus indicates its contamination from food handlers and inadequately cleaned equipment (ICMSF, 1978). Thus, the high counts of S. aureus in examined meat product samples may reflect the amount of handling and when the conditions are favorable for growth and multiplication of such organism enterotoxins are produced and subsequently the food is dangerous (NAS, 1985).

All food of animal origin may be a vehicle transmission of Salmonellae to man. Meat and chicken products may be contaminated by human excreta at any step in the chain of processing during handling from raw material in the preparation of such food in kitchen (Fathi et al., 1994). In the current study, Salmonella spp. failed to be isolated from luncheon samples this result agreed with ELDosoky et al. (2013), Ouf-Jehan (2001), EleiewaNesreen (2003) and Sharaf-Eman et al. (2011). Meanwhile, Ahmed- Zeineb (2012) and Mohamed (2013) could isolated Salmonella spp. from luncheon samples. Absence of Salmonella spp. in luncheon could be due to heat treatment during manufacture and presence of chemical preservatives Hosein et al. (2008). These positive results exceeded permissible limit recorded by E.O.S. (2005a-b-d) as negative salmonella.

Furthermore, similar results found by Mohamed (2013) (40\% in minced meat) and Hassanien-Fatin (2004) (12\% in sausages). low results founded by Stock and Stolle (2001) (15.8\% in minced meat) and Sharma et al. (2002) (3.23\% in kofta). Higher results founded by Fritzen et al. (2006) $(69.5 \%$ in minced meat) and Mrema-Neema et al. (2006) (26\% in sausage) The identified Salmonella spp. isolates in some extend agreed with HassanienFatin, (2004) who isolated (S. Typhimurium and S. Enteritidis in sausage) and Mrema- Neema et al., (2006) Since Salmonella. Typhi is mostly associated with humans Forsythe (2000) who suggested that the food handlers also contributed to the contamination of these meat products. Historically, S. Typhimurium has been the most frequent serotype and $S$. enteritidis acts as a causative agent of human gastroenteritis throughout the world. An annual average of 186 cases was recorded during 1982-1986 in Norway Sharma et al. (1996). The presence of even small numbers of Salmonella in carcass meat and edible offal may lead to heavy contamination of minced meat and sausage when meat is cut into pieces; more microorganisms are added to the surfaces of exposed tissue. Raw meats, particularly minced meats have very high total counts of microorganisms and Salmonellae are likely to be present in large numbers Darwish et al. (1986).

The incidence of E-Coli (table 4) were nearly similar to those obtained by Ouf-Jehan (2001) ( $25 \%$ in sausages). Higher result by Zaki-Eman (2003) (40\% in sausages) and lower ones founded by Abou-Hassien-Reham (2004) (12\% in sausages). Meanwhile, presence of $E$. Coli in meat indicates a general lack of cleanness during slaughtering, evisceration, dressing, transportation and handling of meat ICMSF, (1996). The identified E-Coli. isolates similar found by Hassanien-Fatin (2004) (O124:K72 in sausage). In Egypt, Marzonk (1985) incriminated EPEC as a cause of $54 \%$ of diarrhoea in infants. On the other hand, EHEC (O111) was implicated in severe outbreaks of diarrhea in young children (Evans et al. 1979) characterized by sudden onset of severe crampy abdominal pain followed, by watery diarrhoea with later becomes grossly bloody. In the summer of 1976, more than 2200 visitors at a national park in USA suffered from diarrhea due to consumption of sausage contaminated with ETEC (O128) producing heat labile toxin (Rosenberg et al., 1977). These positive results exceeded permissible limit recommended by E.O.S. (2005ab-d) as negative E-Coli.

The variation in the results between different authors may be due to the differences in manufacture practices, handling from producers to consumers and the effectiveness of hygienic measures applied during production. The presence of $E$. coli in food is considered as an indicator of faults during preparation, handling, storage or service. So there are 3 main routes by which microorganisms enter the food through raw food used, food handlers and the surrounding environment. Fecal contamination of the carcass can act as cross contamination of raw food which is never sterile and careful working practices are essential source of $E$. coli infection Roberts (1990).

Finally, the current study allows to conclude that the possibility of contamination of meat products with such serious pathogens remains as a public health problem. Thus all precautions of proper sanitation during manufacture, handling and 
storage of such meat products should be adopted to control these serious pathogens and to obtain a maximum limit of safety to consumers.

\section{REFERENCES}

Abou-Hussien-Reham, A.A. 2004. Microbial evaluation of some meat products. M. V. Sc. Thesis, Meat hygiene, Fac. Vet. Med., Moshtohor, Zagazig Univ., Benha branch.

Ahmed- Zeineb, A.M. 2012. Prevalence of Salmonellae in poultry products and meat products in Luxor City . M. V. Sc. Thesis, Meat Hygiene , Fac . Vet. Med., South Valley,Univ.

Al- Kour, M.S. 2001. microbiological states of meat and some meat products in northern Jordan. M.V.Sc. Thesis, Fac. Vet. Med., Jordan University of Science and Technology.

APHA "American Public Health Association" 1984. Compendium of methods for microbiological examination of foods . 2nd Ed., APHA, Washington D. C.

APHA "American Public Health Association " 1992. Compendium of Methods for the microbiological examination of foods. American Public Health Association, Washington, D.C., USA., 105: 100-110.

Borch, E., Arinda, P. 2002. Bacteriological safety issues in red meat and ready - to -eat meat product, as well as control measures. J. Meat Sci., 62: 381-390.

Cruz, R., Fuentes, M., Gusils, C., Pugamenilaharzu, H. 2005. Microbiological analysis of crude and ready-to-eat meats. J. Food Technol.,3: 130-134.

Darwish, M.A., Roqiah, G.B., Sayed, S.M. 1986. Salmonella in minced beef compared to beef carcasses. J. Food Protct., 50:122-133.

Donald, F.V.S., Yuhuan, C., Pristine, M.J., Fabiola, P.C. 2001. Quantification and variability analysis of bacterial crosscontamination rates in common food service tasks. J. Food Protect., 64: 72-80.

El-Dosoky, H.F.A., Shafik, S., Baher, M. Weam. 2013. detection of spoilage and food poisoning bacteria in some ready to eat meat products in dakahlia governorate. Assiut Vet. Med. J.,59: 55-59.

Eleiewa-Nesreen, Z.H. 2003. effect of chemical preservatives on food poisoning bacteria in some locally manufactured meat products. Ph.D. Thesis, Fac. Vet. Med., Zagazig University.
E.O.S. (Egyptian Organization For Standarization and Quality Control) 2005a.Egyptian standards for requirements of sausage, No $: 1972$.

E.O.S. (Egyptian Organization For Standarization and Quality Control) 2005b.Egyptian standards for requirements of minced meat , No :1694.

E.O.S. (Egyptian Organization For Standarization and Quality Control) 2005c.Egyptian standards for requirements of luncheon meat , No :1114

E.O.S. (Egyptian Organization For Standarization and Quality Control) 2005d. Egyptian standards for requirements of kofta, No. 1688.

Erdem-Ayten, k., Saglam, D., Ozer, D., Ozcelik, E. 2014. Microbiological Quality of Minced Meat Samples Marketed in Istanbul YYU Veteriner Fakultesi Dergisi., 25: $67-70$.

Evans, D., Evans, O., Doupont, H. 1979. Haemagglutination patterns of enterotoxigenic and enteropathogenic E.coli determined with human, bovine, chicken and guinea pig erthrocytes in the presence of absence of mannose. J. Food protect., 5: 1051.

Fathi, S. El-Kateib, T., Moustafa, S., Hassanein, K. 1994. Salmonellae and Enteropathogenic E. coli in some locally manufactured meat products. Assiut. J. Vet. Med., 31: 190-199.

Feng, P., Weagent, S.D., Grant, M.A. 2002. Bacteriological analytical manual. Online. www. lib.ncsu.edu/ pubweb/ www/ ETDdb/web_root/collection/available/etd04102005-213953/ unrestricted/ etd.pdf.

Forsythe, S.J. 2000. The microbiology of safe food. Oxford, UK: Blackwell Science Ltd.

Fritzen, A.L., Schwerz, D.L., Gabiatti, E.C., Padilha, V., Macari, S. M. 2006. Microbiological analysis of minced meat from slaughter houses in the $9^{\text {th }}$ health region in Parana. [Portuguese]. Rev. Hyg. Alim., 20: 81-83.

Gönülalan, Z., Köse, A. 2003. Kayseri ilinde satışa sunulan sığır kıymalarının mikrobiyolojik kalitesi. FÜ Sağllk Bil Derg, 17: 49-53.

Grimont, P.A.D., Weil, F.X. 2007. Antigenic formula of the Salmonella serovars. WHO Collaborating Centre for Reference and Research on Salmonella, $9^{\text {th }}$ edition Paris, France.

Hassanien-Fatin, A. 2004. Bacterial Hazards Associated with Consumption of Some Meat Products. Benha, Vet.Med.J., 15: 41-54.

Hosein, A., Muñoz, K., Sawh, K., Adesiyun, A. 2008. Microbial load and the prevalence of 
Escherichia coli, Salmonella spp. and Listeria spp. In ready-to-eat products in Trinidad. The Open Food Sci. J., 2: 23-28.

"ICMSF" International Commission and Microbiological Specification for Foods 1978. Microorganisms in Foods: Their significance and method of enumeration, 2nd Ed., Univ. of Tronto. Press, Tronto, London.

ICMSF "International Commission and Microbiological Specification for Foods" 1996. Microorganisms in foods. Intestinally pathogenic E. coli. Blackie Academic and Professional, London, UK.

ISO (International Standard Organization) 2002. $4^{\text {th }}$ Ed. Microbiology - General guidance on methods for the detection of Salmonella, International Organization for Standardization, Geneve, Switzerland.

Jay, J.M. 1997. Modern food microbiology, $4^{\text {th }}$ Ed., Chapman and Hall, International Thomson publishing, NewYork.

Kauffman, G. 1974. Kauffmann white scheme. J. Acta. Path. Microbiol. Sci., 61: 385.

Marzouk, I. 1985. A study on microbial etiology of infantile diarrhoea, related serum electrolyte changes and agent related efficiency of antisecretory drugs (Chlorpromezine). M. D, Pediatrics, Fac. Med., Alex. University.

Mohamed, K. 2013.Prevalence of Salmonella in Meat Products.J. Global Veterinaria., 11: 685-688.

Morshdy Alaa El-Deen, M., El-Atabany Adel, L., Hussein Mohamed, A., Nasser Mohammad, A. 2013.detection of entertoxigenic staphylococcus aureus in some meat products. Assiut. Vet. Med.J.,59:100-106.

Mrema- Neema, Sisai Mpuchane, Berhanu A. Gashe. 2006. Prevalence of Salmonella in raw minced meat, raw fresh sausages and raw burger patties from retail outlets in Gaborone, Botswana. Food Control., 17:207-212.

Naomi Balaban, Avraham, Rasooly. 2000. Staphylococcal enterotoxins Int. J. Food Microbiol., 61: 1-10.

NAS 1985. National Academy of sciences. An evaluation of the role of microbiological criteria for foods and food ingredients. National Academy of science, Washington D. C.

Nørrung, B.J., Andersen, K., Buncic, S. 2009. Main Concerns of Pathogenic Microorganisms in Meat Safety of Meat and Processed Meat. F. Toldrá, ed. (Springer New York)., 3-29.
Ouf-Jehan, M. 2001. microorganisms of sanitary importance in some meat products and their additives. Ph.D. Thesis, Fac. Vet. Med., Cairo Univ.

Rajic, A., Waddell, L.A., Sargeant, J.M., Read, S.J., Farber, M.J., Firth, A. Chambers, 2007.An overview of microbial food safety programs in beef, pork, and poultry from farm to processing in Canada. J. Food Protect., 70: 1286-1294.

Roberts, D. 1990. Sources of food infection. Lancet-British-edition, 336: 8719-859.

Rosenberg, M., Koplan, J., Wachsmuth, I., Wells, T., Gangarosa, E. Guerrant, R., Sack, D. 1977. Epedemic diarrhea at carter lake from Enterotoxigenic E. coli. A large water borne outbreak. Annual Inter. Med., 86: 714 - 718.

Salem-Amany, M., Amin-Reham, A., Afifi-Gehan, S.A. 2010. Studies on Antimicrobial and Antioxidant Efficiency of Some Essential Oils in Minced Beef. J. American Sci., 6: 691-700.

Sharaf- Eman, M., Mezyed-Ebresam, M., AfifiGehan, S. 2011. Microbiological studies on salmonella microorganism in some meat products.Assiut Vet.Med.J., 57: 127-136.

Sharma, D., Sharma, V.D., Kumar, A. 1996. Microbial quality of commercial pork products. Indian. J. Animal Sci., 66: 211213.

Sharma, V. D., Barman, T. K., Subodh Kumar. 2002. Contamination of pork products with Salmonella serovars. Indian. J. Animal Sci., 72: 718-720.

Stock, K., Stolle, A. 2001. Incidence of Salmonella in minced meat produced in a European Union-approved cutting plant. J.Food Protect., 64: 1435-1438.

Varnam, A.H., Evans, M.G. 1991. Salmonella. In: Foodborne pathogens. An illustrated text. Eds: Varnam A.H. and Evans M.G. Wolfe Publishing Ltd, Aylesbury, England.

Vipham, J.L., Brashears, M.M., Loneragon, G.H., Echeverry, A., Brooks, J.C., Chaney, W.E., Miller, M.F. 2012. Salmonella and Campylobacter baseline in retail ground beef and whole-muscle cuts purchased during 2010 in the United States. J. Food Protect., 75: 2110-2115.

Wells, S.J., Fedorka-Cray, p.J., Dargartz, D.A., Ferris, K., Green, A. 2001. Faecal shedding of Salmonella spp. by dairy cowson farm and at cull cow markets. J. Food Protect., 64: $3-11$.

Yadav, M.M., Tale, S., Sharda, R., Sharma, V., Tiwari, S., Garg, U.K. 2006. Bacteriological quality of sheep meat in Mhow town of 
Studies on bacteriological Profile of some meat products

India. Inter. J. Food Sci. Technol., 41: 12341238.

Zaki- Eman, M.S. 2003. Risk assessment of ready prepared meat products. Ph.D.Thesis, Meat Hygiene. Fac. Vet. Med., Cairo Univ.
Zaharan-Dalia, A., Bassma, A.H., El. Hifnawi, H.N. 2008. Incidence and radiation sensitivity of Bacillus cereus, Listeria monocytogenes and their toxins in some chicken products. World Appl. Sci. J., 5: 182-188. 